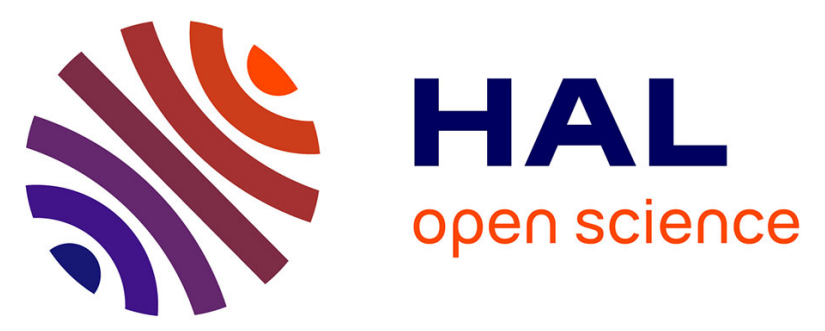

\title{
Impact of blade tenderization, marinade and cooking temperature on oral comfort when eating meat in an elderly population
}

Mathilde Vandenberghe-Descamps, Claire Sulmont-Rossé, Chantal Septier, Claire Follot, Gilles Feron, Hélène Labouré

\section{To cite this version:}

Mathilde Vandenberghe-Descamps, Claire Sulmont-Rossé, Chantal Septier, Claire Follot, Gilles Feron, et al.. Impact of blade tenderization, marinade and cooking temperature on oral comfort when eating meat in an elderly population. Meat Science, 2018, 145, pp.86-93. 10.1016/j.meatsci.2018.06.004 . hal-02142093

\section{HAL Id: hal-02142093 \\ https://institut-agro-dijon.hal.science/hal-02142093}

Submitted on 26 May 2020

HAL is a multi-disciplinary open access archive for the deposit and dissemination of scientific research documents, whether they are published or not. The documents may come from teaching and research institutions in France or abroad, or from public or private research centers.
L'archive ouverte pluridisciplinaire HAL, est destinée au dépôt et à la diffusion de documents scientifiques de niveau recherche, publiés ou non, émanant des établissements d'enseignement et de recherche français ou étrangers, des laboratoires publics ou privés.

\section{(1) $(1) \Theta$}

Distributed under a Creative Commons Attribution - NonCommercial - NoDerivatives| 4.0 


\section{Accepted Manuscript}

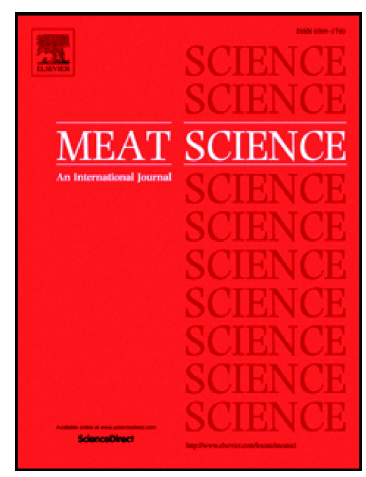

Mathilde Vandenberghe-Descamps, Claire Sulmont-Rossé, Chantal Septier, Claire Follot, Gilles Feron, Hélène Labouré

PII:

S0309-1740(18)30084-6

DOI: doi:10.1016/j.meatsci.2018.06.004

Reference:

MESC 7577

To appear in:

Meat Science

Received date:

30 January 2018

Revised date:

24 May 2018

Accepted date:

4 June 2018

Please cite this article as: Mathilde Vandenberghe-Descamps, Claire Sulmont-Rossé, Chantal Septier, Claire Follot, Gilles Feron, Hélène Labouré , Impact of blade tenderization, marinade and cooking temperature on oral comfort when eating meat in an elderly population. Mesc (2017), doi:10.1016/j.meatsci.2018.06.004

This is a PDF file of an unedited manuscript that has been accepted for publication. As a service to our customers we are providing this early version of the manuscript. The manuscript will undergo copyediting, typesetting, and review of the resulting proof before it is published in its final form. Please note that during the production process errors may be discovered which could affect the content, and all legal disclaimers that apply to the journal pertain. 
Impact of blade tenderization, marinade and cooking temperature on oral comfort when eating meat in an elderly population

Mathilde Vandenberghe-Descamps ${ }^{\mathrm{a}}$, Claire Sulmont-Rossé ${ }^{\mathrm{a}}$, Chantal Septier ${ }^{\mathrm{a}}$, Claire Follot $^{\mathrm{a}}$, Gilles Feron ${ }^{a^{*}}$, Hélène Labouré ${ }^{\mathrm{a}}$

${ }^{\text {a }}$ Centre des Sciences du Goût et de l'Alimentation, AgroSup Dijon, CNRS, INRA, Univ. Bourgogne Franche-Comté, F-21000 Dijon, France.

* Corresponding author: Dr Gilles FERON, INRA-CSGA, 17 rue Sully, 21065 Dijon, France. E-mail address: gilles.feron@inra.fr 


\begin{abstract}
Several studies demonstrated that oral health impairment, such as tooth loss or a decrease in salivary flow might lead elderly people to reduce their meat intake. The present study assessed the impact of culinary processes liable to improve meat texture and smooth down meat oral processing, in order to fulfil the oral capacities of elderly people. Four culinary processes were selected: cooking bag, blade tenderizer, marinade and low-temperature cooking. A panel of 40 elderly participants with good and poor dental status were asked to assess 5 chicken breast samples, 5 roast beef samples and 4 beefsteak samples prepared according to different process conditions by using an "oral comfort" questionnaire. Results highlighted the fact that oral impairment may alter food bolus formation as well as texture perception while eating meat in elderly people. Furthermore, they revealed that easy-to-do culinary processes may improve meat tenderness and juiciness as well as smooth down food bolus formation, in particular for the roast beef.
\end{abstract}

Keywords: older adult; food bolus; texture; oral health; denture; saliva 


\section{Introduction}

With aging, oral health impairments can occur and lead to difficulties in masticating, humidifying food with saliva or even swallowing foods. Oral health degradation such as tooth loss (Auvray, Doussin, \& Le Fur, 2003; Hoffmann et al., 2006), wearing of dentures (Asakawa, Fueki, \& Ohyama, 2005), decrease in muscle strength (Goodpaster et al., 2006; Peyron, Blanc, Lund, \& Woda, 2004), lack of saliva (Mathilde Vandenberghe-Descamps et al., 2016) and impaired swallowing (Humbert \& Robbins, 2008; Tracy et al., 1989) can alter food consumption (Cousson et al., 2012; Geissler \& Bates, 1984; Joshipura, Willett, \& Douglass, 1996; Lee et al., 2004; Marcenes, Steele, Sheiham, \& Walls, 2003; MuñozGonzález et al., 2017; Sura, Madhavan, Carnaby, \& Crary, 2012). Regarding meat consumption, Lee et al. (2004) highlighted that edentate participants had lower intake in hardto-chew foods, including fried chicken and beef, compared to dentate elderly participants. Another study led by Marcenes et al. (2003) showed that edentulous elderly people had significantly greater difficulty eating well-done steaks compared to dentate elderly participants. However, consuming an appropriate amount of meat according to the body's needs, thereby having a sufficient intake of proteins, is essential for preventing muscle loss and in the end malnutrition in elderly people (Beasley, Shikany, \& Thomson, 2013; PaddonJones, Short, Campbell, Volpi, \& Wolfe, 2008). Therefore, it is of crucial importance to develop meat products that have an adapted texture for the elderly's masticatory ability.

Many studies have investigated the improvement of meat texture through the use of culinary processes (Aktaş, Aksu, \& Kaya, 2003; Burke \& Monahan, 2003; Davis, Smith, \& Carpenter, 1977; Hayward, Hunt, Kastner, \& Kropf, 1980; Jeremiah, Gibson, \& Cunningham, 1999; Oreskovich, Bechtel, McKeith, Novakofski, \& Basgall, 1992; Savell, Smith, \& Carpenter, 1977). Among the techniques are blade tenderization and marinating, which are largely 
represented in the literature. Cooking temperature is also known to have an impact on meat characteristics.

Blade tenderization consists of perforation of the meat with sharp edged blades that are closely spaced to cut muscle fibers (Pietrasik \& Shand, 2004) and is one of the most effective interventions currently used to ensure tenderness (King et al., 2009). Many authors have reported that one or two passages depending on the meat category and muscle type were sufficient to increase meat tenderness and overall meat palatability (King et al., 2009; Obuz, Akkaya, Gök, \& Dikeman, 2014; Pietrasik, Aalhus, Gibson, \& Shand, 2010). Obuz et al. (2014) have for example studied the impact of a blade tenderizer on meat characteristics using shear force evaluation and sensory analysis. The authors showed a decrease in the shear force value and an increase in the tenderness assessment with the use of a blade tenderizer passed two times on the meat. Regarding marinade, many authors have highlighted its impact on meat palatability. Made of red wine, citrus juice or even soy sauce, the effects of marinade on meat texture characteristics have been largely explored (Aktaş et al., 2003; Burke \& Monahan, 2003; Kim et al., 2013; Oreskovich et al., 1992). Kim et al. (2013) have for example investigated the impact of a soy sauce marinade on meat tenderness using rheological measurements. The results showed a decrease in shear force with increasing soy sauce concentration in the marinades. Finally, cooking temperature is known to have an impact on mechanical properties, as soluble collagen in meat increases with greater cooking temperature and soluble protein decreases when cooking temperature increases (Davey \& Gilbert, 1974; Murphy \& Marks, 2000). Furthermore, several authors have shown an increase in cooking loss, i.e. the amount of meat juice exudate during cooking, with increasing cooking temperature (Barbanti \& Pasquini, 2005; Bouton \& Harris, 1972).

Even though these processes seem promising to soften and/or moisten meat products, they have never been tested for acceptability in an elderly population, members of which are 
known to be less sensitive to texture perception than younger adults (Conroy, O' Sullivan, Hamill, \& Kerry, 2017). Consequently, the aim of the present experiment was to test culinary processes and ask an elderly panel to assess oral comfort when eating the samples. In addition, the elderly's oral health was characterized to investigate the impact of oral health on meat acceptability. To this end, we asked elderly people to rate the oral comfort of 3 meat products prepared according to different process conditions using the "oral comfort" questionnaire developed in a previous study (Mathilde Vandenberghe-Descamps, Labouré, Septier, Feron, \& Sulmont-Rossé, 2017).

\section{Materials and Methods}

\section{Participants}

Two groups of 20 older adults ( $\geq 65$ years old) were recruited, one group with a good dental status (10 women and 10 men; age mean: 72.8 yo; age range: $66-87)$ and one group with a poor dental status (11 women and 9 men; age mean: 74.7 yo; age range: $67-89$ ). According to Leake, Hawkins, and Locker (1994), the number of functional units was used to characterize elderly people's dental status. A functional unit was defined as a pair of posterior antagonist teeth that had at least one contact area during chewing. The number of functional units was evaluated by asking the participants to chew 1-2 cycles on 200-mm thick articulating paper; the number of teeth on the mandibular arch that had at least one color mark provided the number of functional units. Elderly people with at least 7 functional units and not wearing a removable denture were considered as having a good dental status; elderly people with 4 or less functional units and possibly wearing a removable denture were considered as having a poor dental status. The other recruitment criteria were the following: older than 65 years old, living at home, no acute pathological episodes neither at the time of the experiment nor in the recent past, a score of at least 24 on the mini mental state evaluation (MMSE) (Folstein, 
Folstein, \& McHugh, 1975). An interview was carried out with each volunteer to ensure that they met the inclusion criteria. In parallel, the resting and stimulated salivary flows of every volunteer were measured by instructing the participant to spit out the saliva into a preweighed screw-cap cup every time they felt like swallowing. The measurement of resting salivary flow was over a period of $10 \mathrm{~min}$ and the measurement of stimulated salivary flow lasted 5 minutes during which the participants were asked to masticate a piece of preweighted parafilm while spitting saliva. The salivary flow rate was expressed in $\mathrm{ml} / \mathrm{min}$, assuming that $1 \mathrm{~g}$ of saliva corresponded to $1 \mathrm{ml}$.

\section{Products}

Three meat products were chosen for the present study: chicken breast, roast beef and beefsteak. All the products were provided by a butcher and each meat was provided from the same batch. Four culinary processes were selected: cooking bag (Albal®), blade tenderizer, marinade and low-temperature cooking. These processes were chosen because they are easy to implement in everyone's kitchen (they do not need expensive or complex devices) and/or because they proved to have a positive impact on meat tenderness and/or juiciness in the scientific literature. As it was not possible to ask the elderly participants to taste all the possible combinations made with these four culinary processes, preliminary tests were conducted $i$. to select the most promising processes and/or combinations of processes, and $i$. to set up the protocol for each culinary processes. For these preliminary tests, several assays were achieved and evaluated through two physical measurements: the shear force evaluation, which was demonstrated to be correlated with meat tenderness (Obuz et al., 2014; Pietrasik et al., 2010) and water content. Shear force, which corresponds to the force necessary to cut the sample, was measured by using a Warner-Bratzler (V-shaped cutting blade) attachment positioned on an electronic testing machine (ttc ${ }^{\circledR}$ TA.XT plus) at a crosshead speed of 
$2 \mathrm{~mm} / \mathrm{sec}$. Water content was evaluated by weighing a sample before and after dehydration in an oven at $130^{\circ} \mathrm{C}$ for 24 hours.

Based on the results of these preliminary tests (Vandenberghe-Descamps, Sulmont-Rossé, Feron, \& Labouré, submitted), five "process" conditions were selected for chicken breast and roast beef and four conditions were selected for beefsteak (Table 1).

\section{Cooking bag}

The meat was put in a tightly closed cooking bag (Albal®). Such cooking bags can be easily found in supermarket and more or less mimic stewing condition.

\section{Blade tenderizer}

Blade tenderization (BT) consists in the perforation of the meat with sharpened edged blades being closely spaced in order to cut muscle fibers (Figure 1). In the present experiment, it was performed by using a blade tenderizer Hendi Profi Line 51 blades. One pass was done on each sample, on the top side for chicken breast and beefsteak samples and on both sides for the roast beef samples which were too thick for the blade tenderizer to pass through. No visual difference could be made between control and blade-tenderized samples by the participants.

\section{Marinade}

The marinade (M) was made of $6 \%$ of soy sauce and $94 \%$ of water. The chicken breast and beefsteaks stayed in the marinade for 2 hours at $+4^{\circ} \mathrm{C}$ and the roast beef stayed for 4 hours at $+4^{\circ} \mathrm{C}$. For blade tenderizer and marinade samples (BT-M), blade tenderization was made before plunging the meat in the marinade.

\section{Low-temperature cooking}


Low-temperature (LT) samples for chicken breast and roast beef were cooked in an oven at $110^{\circ} \mathrm{C}$ until reaching $+65^{\circ} \mathrm{C}$ at the center of the product. The time needed to cook the meat at low-temperature was approximatively 60 minutes for chicken breast and 77 minutes for roast beef.

The samples were cooked right before serving. The beefsteak samples were cooked on a frying pan heated at $160^{\circ} \mathrm{C}$. The chicken breast and roast beef samples cooked under standard condition (i.e. not a low-temperature cooking) were put in an oven at $220^{\circ} \mathrm{C}$ until reaching $+65^{\circ} \mathrm{C}$ at the center of the product. The time needed to cook the meat under standard condition was approximatively 25 minutes for chicken breast, 31 minutes for roast beef and 6 minutes for beefsteak. The temperature was controlled by using a cooking thermometer which measuring tube was sank to reach the center of the product.

\section{Oral comfort assessment}

In a recent study, we conducted focus groups asking elderly people to define the concept of oral comfort during food consumption (Mathilde Vandenberghe-Descamps et al., 2017). The results highlighted five important categories to consider when evaluating the easiness to eat: food bolus formation, time needed to form the food bolus, pain sensations felt when eating, texture perception and taste perception. Inside the texture category, 10 attributes were considered relevant to characterizing food oral processing: sticky, stringy, greasy, dry, doughy, melting, firm, hard, tender and juicy. A questionnaire aimed at evaluating oral comfort when eating a food was developed using the results of the focus groups. This questionnaire was used in the present study to assess oral comfort when eating meats (Figure 2). 


\section{Procedure}

The participants were invited to take part in three tasting sessions, one for each type of meat. The sessions either took place at $11 \mathrm{AM}$ or at $6 \mathrm{PM}$ (i.e., close to French lunch and dinner hours). At the beginning of each session, the oral comfort questionnaire was presented to the participants by the experimenter. Then the participants were served with the five (chicken breast, roast beef) or the four (beefsteak) samples. After tasting a product, the participants were asked to complete the oral comfort questionnaire. They were free to bite the products as many times as they wanted in order to answer the questions. After each sample, they were given a 3-minutes rest time; participants were free to drink as much water as they needed.

The sessions were conducted in a sensory room equipped with individual booths according to the AFNOR standard (AFNOR, 1987) and under white light. The room temperature was $20.5 \pm 0.5^{\circ} \mathrm{C}$. The products were presented in an order determined by a William Latin square design and they were coded with a three-digit number. Portion size were $70 \mathrm{~g}$ for chicken breast, $50 \mathrm{~g}$ for roast beef and $40 \mathrm{~g}$ for beefsteak (portion size were determined to be sufficient for answering the entire questionnaire).

\section{Data analysis}

Separate analyses were conducted for the chicken breast, roast beef and beefsteak to study the impact of culinary processes on oral comfort. For each item of the oral comfort questionnaire, scores were submitted to Analysis of Variance (ANOVA) with one factor (sample) after checking for normality. A global analysis was conducted to investigate the impact of oral health on oral comfort. For each item of the oral comfort questionnaire, scores were submitted to an Analysis of Covariance (ANCOVA) with three factors: product (chicken breast, roast beef and beefsteak), dental status (poor; good) and salivary flow. As the interaction product $x$ dental status was not significant, the results of the interaction were not described below. Post 
hoc comparisons were performed using the Student Newman Keuls test. Means (M) were associated with their standard errors (SEM). The threshold for significance was set at $5 \%$. Statistical analyses were conducted using R-studio software version 3.3.1 with the "nlme" package for linear mixed models and the "agricolae" package for post hoc analyses (de Mendiburu, 2017).

\section{Results}

\section{Impact of culinary processes on oral comfort assessment}

\section{Results on chicken breast}

There was no significant difference between the samples regarding the general question of oral comfort (Table 2). However, the samples were rated as significantly different on the texture attributes dry and melting ( $p<0.05$ and $p<0.01$ respectively) (Figure 3$)$. According to post hoc analysis, the sample that was blade-tenderized and cooked at low-temperature was rated as less dry and less melting than the control sample. Blade-tenderization alone (BT) or low-temperature cooking alone did not significantly improve product texture compared to the control sample.

\section{Results on roast beef}

A significant sample effect was observed for the general question on oral comfort as well as on several attributes related to food bolus formation and product texture (Table 2). Regarding the general question, low-temperature cooking alone was not enough to increase oral comfort compared to the control sample cooked at high-temperature. However, the combination of low-temperature cooking with at least one other culinary process (blade tenderizer and/or marinade) led to a significant increase in oral comfort while eating roast beef (Figure 4a). 
Regarding food bolus formation, the combination of low-temperature cooking and marinade (M-LT and BT-M-LT) led to meat samples significantly easier to masticate and easier to humidify than the control sample (Figure 4b). Finally, regarding texture attributes, all the processed samples (LT, BT-LT, M-LT and BT-M-LT) were rated as less dry, more juicy and tenderer than the control sample (Figure 4c). In addition, the BT-M-LT sample was rated as more melting as well as less firm and hard than the control sample.

\section{Results on beefsteak}

There was no significant difference between the samples regarding the general question of oral comfort (Table 2). Only the attribute easiness to cut with the molars was associated with a significant sample effect, but none of the processed samples (i.e., BT, M, BT-M) were significantly different from the control sample (Figure 5).

\section{Impact of oral health on the oral comfort assessment}

No impact of oral health parameters (dental status, resting and stimulated salivary flow) was observed on the general question of oral comfort (Table 3). However, several significant effects were observed on the attributes related to food bolus formation and pain sensations as well as on texture and flavor perception. The interaction product $x$ dental status was never significant, meaning that the two groups rated the products in the same order whatever the attribute. The stimulated salivary flow of elderly people with a good dental status group $(M=1.9 \mathrm{ml} / \mathrm{sec} ; S E M=0.8)$ was significantly higher than the one of elderly people with a poor dental status group $(M=1.3 \mathrm{ml} / \mathrm{sec} ; S E M=0.6 ; t(38)=-2.70 ; p=0.01)$. Not such difference was observed for the resting salivary flow $(t(38)=-0.14 ; p=0.9)$.

Regarding dental status, elderly people with a good dental status found the food bolus easier to humidify with saliva and to swallow and they needed less time to form the food bolus than elderly people with a poor dental status. They also rated the samples as tenderer and juicier as 
well as saltier and more intense in flavor than the latter. Finally, elderly people with a good dental status felt slightly less muscle and articular pain but slightly more gum pain than elderly with a poor dental status.

Regarding resting salivary flow, elderly people with a greater resting salivary flow found the food bolus easier to form than elderly people with a lower resting salivary flow. They also felt slightly less muscular pain but slightly more articular and dental pain than the latter. Finally, elderly people with a greater resting salivary flow rated the product as less sticky, less greasy, less hard, and less intense in flavor than elderly people with a lower resting salivary flow.

Regarding stimulated salivary flow, elderly people with a greater stimulated salivary flow found the food easier to cut with molar but more difficult to humidify, to swallow and needed more time to form the food bolus than elderly people with a lower stimulated salivary flow. Nevertheless, they felt slightly less articular and gum pain than the latter. Finally, elderly people with a greater resting salivary flow rated the product as less doughty, less firm and less bitter than elderly people with a lower resting salivary flow.

\section{Discussion}

The present study demonstrates that using easy-to-do culinary processes could improve oral comfort, easiness to form food bolus and food texture while eating meat in the elderly population. Regarding chicken breast, blade tenderization and low-temperature cooking decreased dryness compared to a control sample cooked at high-temperature without preliminary culinary processes. Regarding roast beef, the cumulative effect of blade tenderization, marinade and low-temperature cooking were the optimal conditions to obtain meat sample easy to chew, to humidly with saliva and to swallow, as well as to a tender and juicy product. Finally, regarding beefsteak, blade tenderization and marinade tended to 
improve easiness to form food bolus by increasing easiness to break down the meat in mouth. It should be noted that stronger effects of culinary processes were observed for chicken breast and roast beef than for beefsteak. This could be explained by the fact that beefsteak samples were made from high-quality beef meat (Charolais local production). This meat may not have needed any improvement to be easy to chew and swallow, and in fact, the control beefsteak sample scored higher on the general comfort item $(M=3,1 ; S E M=0.1)$ than the control chicken breast $(M=2.8 ; S E M=0.1)$ and the control roast beef $(M=1.9 ; S E M=0.1)$. Conversely, the present results support the fact that easy-to-do culinary processes may have a significant impact on medium-quality meat, namely products that are affordable by the majority of the population. This is all the more important as elderly people with a lower socioeconomic status - and who are the less likely to afford high-quality meat - also present poorer dental status and are less likely to get dental care (Bernabé \& Marcenes, 2011; Gilbert, Duncan, \& Shelton, 2003; Marcus, Kaste, \& Brown, 1994).

The present study also highlights that oral health impairments may have a significant impact on food bolus formation and on texture perception, in line with previous authors (Mese \& Matsuo, 2007; Solemdal, Sandvik, Willumsen, Mowe, \& Hummel, 2012; Veyrune \& Mioche, 2000). Regarding food bolus perception, when considering both dental and salivary status, it is interesting to note that a poor dental status mainly alters elderly people's ability to humidify and swallow food bolus, while low resting salivary flow impairs elderly people's ability to break down food products as well as to humidify and swallow food bolus. In addition, elderly people with poorer dental status and lower resting saliva flow needed more time to form food bolus, and elderly people with poorer dental status and lower stimulated salivary flow experienced more pain sensations. Regarding texture perception, elderly people with poor dental status rated the products as dryer and less juicy than elderly people with good dental status, which is in line with the previous results on the impact of dental status on easiness to 
humidify the food. Aside, elderly people with a good dental status and a higher resting salivary flow rated the products as tenderer than elderly people with poor dental status and lower resting salivary flow. These results emphasize the fact that both dentition and saliva may impact food oral processing and thus should be considered when looking at the impact of oral health on eating behavior in an elderly population (actually, previous studies often considered dental status while they seldom considered salivary status; for a review, see Kiesswetter et al., in press; Tada \& Miura, 2014). However, the present experiment also highlights some odd results. In particular, participants with lower stimulated salivary flow reported less difficulty to humidify and swallow food bolus than participants with higher stimulated salivary flow. In fact, elderly people may have adapted their drinking behavior to cope with the lack of saliva when eating a food. In the present study, the participants were free to drink as much water as they wanted during the sessions. It could be hypothesized that elderly people with a low stimulated salivary flow drunk more water during meat consumption, which could have smoothen and even reverse the impact of low stimulated salivary flow rate on food bolus formation.

The present study stands out from previous ones as processed meat samples were evaluated by a non-trained elderly panel, using an "oral comfort" questionnaire. In fact, previous studies on the impact of culinary processes on meat texture used rheological measurements (Barbanti \& Pasquini, 2005; King et al., 2009) or rely on a trained sensory panel (Obuz et al., 2014; Pietrasik et al., 2010). However, the complex dynamics of food deformation in the mouth, responsible of texture sensation cannot be easily included in any single mechanical test (Dransfield, 1996 cited by Mathoniere et al., 2000). Actually, instrumental techniques do not mimic the dynamics of oral motion, rate of force application and salivation and can give low correlations with subjectives assessments (Peyron et al., 1994). Furthermore, trained panels generally include young or middle-aged adults who cannot account for the oral impairments 
frequently observed in an elderly population such as tooth loss, decrease in saliva flow or even swallowing disorders. The aim of the present study was to develop culinary processes liable to improve meat texture and smooth down meat oral processing, in order to fulfil the oral capacities of elderly people. Consequently, the choice was made to recruit the target population - namely elderly people - for sample assessment. However, recruiting elderly people, and in particular elderly people suffering from oral impairment, is quite challenging. In fact, elderly people with poor oral heath are often frail and dependent, and thus less willing to take part in experimental studies (Maître, Symoneaux, \& Sulmont-Rossé, 2015). In order to avoid an over-representation of elderly people with a good oral health (the easiest to recruit), efforts were made during the recruitment to have half participants with a good dental status and half participants with a poor dental status. However, with such criterion, it was not possible to recruit more than 40 participants, because of time constraints (the study had to be made within one month to ensure homogeneity of meat batches and avoid seasonality effect).

\section{Conclusion}

In agreement with scientific literature, the present study highlighted the fact that oral impairment such as a poor dental status or low salivary flow may impair food bolus formation as well as texture perception while eating meat in elderly people. Furthermore, the present study also revealed that easy-to-do culinary processes such as blade tenderization, marinade or low-temperature cooking may improve elderly people's ability to break down the food, to humidify the particles and to swallow food bolus. These techniques may also increase meat tenderness and juiciness. However, the impact of these techniques varied depending on the meat. The most conclusive effects was observed on roast beef and the least conclusive effects on beefsteak. Further research should explore a broader set of culinary processes for a broader set of meat products (various types of meat, and for a given meat, various types of muscle) in 
order to identify the optimum combinations in term of "oral comfort" for elderly people. Anyways, the present study proved that there are easy-to-do culinary solutions to sustain meat intake in elderly people suffering from oral impairment, a key-factor to prevent sarcopenia and malnutrition in these population.

\section{Ethical statements}

The authors have no conflicts of interest to declare. The experimental protocol was approved by the French Ethics Committee for Research (CPP Est III, Nancy, \#15.04.04, ANSM \#2015A00279-40). In accordance with ethical standards, all participants received written and oral information on the study before signing a consent form.

\section{Acknowledgements}

This study is part of AlimaSSenS [ANR-14-CE20-0003-01] funded by the French National Research Agency. This work was also supported by grants from the Regional Council of Burgundy France and the European Funding for Regional Economic Development (FEDER). 


\section{References}

AFNOR. (1987). (Association française de normalisation). Bulletin des Bibliothèques de France (BBF). Available on line : <http://bbf.enssib.fr/consulter/bbf-1987-04-0386001 >. ISSN 1292-8399., 4, 386-388.

Aktaş, N., Aksu, M. I., \& Kaya, M. (2003). The effect of organic acid marination on tenderness, cooking loss and bound water content of beef. Journal of Muscle Foods, 14(3), 181-194. doi: 10.1111/j.1745-4573.2003.tb00699.x

Asakawa, A., Fueki, K., \& Ohyama, T. (2005). Detection of improvement in the masticatory function from old to new removable partial dentures using mixing ability test. Journal of Oral Rehabilitation, 32(9), 629-634. doi: 10.1111/j.1365-2842.2005.01480.x

Auvray, L., Doussin, A., \& Le Fur, P. (2003). Santé, soins et protection sociale en 2002, CREDES.

Barbanti, D., \& Pasquini, M. (2005). Influence of cooking conditions on cooking loss and tenderness of raw and marinated chicken breast meat. LWT - Food Science and Technology, 38(8), 895-901. doi: http://dx.doi.org/10.1016/j.lwt.2004.08.017

Beasley, J. M., Shikany, J. M., \& Thomson, C. A. (2013). The role of dietary protein intake in the prevention of sarcopenia of aging. [Research Support, N I H , Extramural

Review]. Nutr Clin Pract, 28(6), 684-690.

Bernabé, E., \& Marcenes, W. (2011). Income inequality and tooth loss in the United States. $J$ Dent Res, 90(6), 724-729.

Bouton, P. E., \& Harris, P. V. (1972). The effect of cooking temperature and time on some mechanical properties of meat. Journal of Food Science, 37(1), 140-144. doi: 10.1111/j.1365-2621.1972.tb03404.x

Burke, R. M., \& Monahan, F. J. (2003). The tenderisation of shin beef using a citrus juice marinade. Meat Sci, 63(2), 161-168.

Conroy, P. M., O' Sullivan, M. G., Hamill, R. M., \& Kerry, J. P. (2017). Sensory capability of young, middle-aged and elderly Irish assessors to identify beef steaks of varying texture. Meat $\quad$ Science, 132, 125-130. doi: https://doi.org/10.1016/j.meatsci.2017.05.020

Cousson, P. Y., Bessadet, M., Nicolas, E., Veyrune, J.-L., Lesourd, B., \& Lassauzay, C. (2012). Nutritional status, dietary intake and oral quality of life in elderly complete denture wearers. Gerodontology, 29(2), e685-e692. doi: 10.1111/j.17412358.2011.00545.x

Davey, C. L., \& Gilbert, K. V. (1974). Temperature-dependent cooking toughness in beef. $J$ Sci Food Agric, 25(8), 931-938. doi: 10.1002/jsfa.2740250808

Davis, G. W., Smith, G. C., \& Carpenter, Z. L. (1977). Effect of blade tenderization on storage life, retail case life and palatability of beef. Journal of Food Science, 42, 330337.

de Mendiburu, F. (2017). Statistical Procedures for Agricultural Research. Version 1.2-8.

Folstein, M. F., Folstein, S. E., \& McHugh, P. R. (1975). "Mini-mental state". A practical method for grading the cognitive state of patients for the clinician. J Psychiatr Res, 12(3), 189-198.

Geissler, C. A., \& Bates, J. F. (1984). The nutritional effects of tooth loss. American Journal of Clinical Nutrition, 39, 478-489.

Gilbert, G. H., Duncan, R. P., \& Shelton, B. J. (2003). Social determinants of tooth loss. [Research Support, U S Gov't, P H S]. Health Serv Res, 38(6 Pt 2), 1843-1862.

Goodpaster, B. H., Park, S. W., Harris, T. B., Kritchevsky, S. B., Nevitt, M., Schwartz, A. V., ... Newman, A. B. (2006). The loss of skeletal muscle strength, mass, and quality in 
older adults: the health, aging and body composition study. [Research Support, N I H , Intramural]. J Gerontol A Biol Sci Med Sci, 61(10), 1059-1064.

Hayward, L. H., Hunt, M. C., Kastner, C. L., \& Kropf, D. H. (1980). Blade tenderization effects on beef longissimis sensory and instron textural measurements. Journal of Food Science, 45(4), 925-935. doi: 10.1111/j.1365-2621.1980.tb07480.x

Hoffmann, T., John, M., Kerschbaum, T., Micheelis, W., Potthoff, P., Reich, E., . . . Schroeder, E. (2006). Vierte Deutsche Mundgesundheitsstudie (DMS IV). Köln. Mikrozensus: Fragen zur Gesundheit (2009a): Verteilung der Bevölkerung auf BodyMass-Index-Gruppen in.

Humbert, I. A., \& Robbins, J. (2008). Dysphagia in the elderly. [Review]. Phys Med Rehabil Clin NAm, 19(4), 853-866, ix-x. doi: 10.1016/j.pmr.2008.06.002

Jeremiah, L. E., Gibson, L. L., \& Cunningham, B. (1999). The influence of mechanical tenderization on the palatability of certain bovine muscles. Food Research International, 32(8), 585-591.

Joshipura, K. J., Willett, W. C., \& Douglass, C. W. (1996). The impact of edentulousness on food and nutrient intake. The Journal of the American Dental Association, 127(4), 459-467. doi: http://dx.doi.org/10.14219/jada.archive.1996.0237

Kiesswetter, E., Donini, L., Migliaccio, S., Poggiogalle, E., Sulmont-Rossé, C., Feart, C., . . . Volkert, D. (in press). Functional determinants of dietary intake in communitydwelling older adults - a DEDIPAC systematic literature review. Public Health Nutr.

Kim, H. W., Choi, Y. S., Choi, J. H., Kim, H. Y., Lee, M. A., Hwang, K. E., . . . Kim, C. J. (2013). Tenderization effect of soy sauce on beef M. biceps femoris. [Evaluation Studies

Research Support, Non-U.S. Gov't]. Food Chem, 139(1-4), 597-603. doi: 10.1016/j.foodchem.2013.01.050

King, D. A., Wheeler, T. L., Shackelford, S. D., Pfeiffer, K. D., Nickelson, R., \& Koohmaraie, M. (2009). Effect of blade tenderization, aging time, and aging temperature on tenderness of beef longissimus lumborum and gluteus medius. [Research Support, N.I.H., Extramural

Research Support, Non-U.S. Gov't]. J Anim Sci, 87(9), 2952-2960. doi: 10.2527/jas.20091803

Leake, J. L., Hawkins, R., \& Locker, D. (1994). Social and functional impact of reduced posterior dental units in older adults. J Oral Rehabil, 21(1), 1-10.

Lee, J. S., Weyant, R. J., Corby, P., Kritchevsky, S. B., Harris, T. B., Rooks, R., . . Newman, A. B. (2004). Edentulism and nutritional status in a biracial sample of wellfunctioning, community-dwelling elderly: the health, aging, and body composition study. [Research Support, U S Gov't, P H S]. Am J Clin Nutr, 79(2), 295-302.

Maître, I., Symoneaux, R., \& Sulmont-Rossé, C. (2015). Sensory testing in new product development: working with older people. Maître I, Symoneaux $R \&$ Sulmont-Rossé $C$ (2015). Sensory testing in new product development: working with older people. In Delarue J, Lawlor B \& Rogeaux M (eds), Rapid sensory profiling techniques and related methods (pp. 485-208). Woodhead Publishing Limited, Cambridge, UK.

Marcenes, W., Steele, J. G., Sheiham, A., \& Walls, A. W. (2003). The relationship between dental status, food selection, nutrient intake, nutritional status, and body mass index in older people. Cadernos de Saude Publica, 19(3), 809-816.

Marcus, S. E., Kaste, L. M., \& Brown, L. J. (1994). Prevalence and demographic correlates of tooth loss among the elderly in the United States. [Comparative Study]. Spec Care Dentist, 14(3), 123-127. 
Mathonière, C., Mioche, L., Dransfield, E., Culioli, J. (2000) Meat texture characterisation: comparison of chewing patterns, sensory and mechnical measures. Journal of Texture Study, 31, 183-203.

Mese, H., \& Matsuo, R. (2007). Salivary secretion, taste and hyposalivation. Journal of Oral Rehabilitation, 34(10), 711-723.

Muñoz-González, C., Vandenberghe-Descamps, M., Feron, G., Canon, F., Labouré, H., \& Sulmont-Rossé, C. (2017). Association between salivary hypofunction and food consumption in the elderlies. A systematic literature review. [journal article]. The journal of nutrition, health \& aging. doi: 10.1007/s12603-017-0960-x

Murphy, R. Y., \& Marks, B. P. (2000). Effect of meat temperature on proteins, texture, and cook loss for ground chicken breast patties. [Research Support, Non-U S Gov't]. Poult Sci, 79(1), 99-104.

Obuz, E., Akkaya, L., Gök, V., \& Dikeman, M. E. (2014). Effects of blade tenderization, aging method and aging time on meat quality characteristics of Longissimus lumborum steaks from cull Holstein cows. Meat Sci, 96(3), 1227-1232. doi: https://doi.org/10.1016/j.meatsci.2013.11.015

Oreskovich, D. C., Bechtel, P. J., McKeith, F. K., Novakofski, J., \& Basgall, E. J. (1992). Marinade pH Affects Textural Properties of Beef. Journal of Food Science, 57(2), 305-311. doi: 10.1111/j.1365-2621.1992.tb05482.x

Paddon-Jones, D., Short, K. R., Campbell, W. W., Volpi, E., \& Wolfe, R. R. (2008). Role of dietary protein in the sarcopenia of aging. Am J Clin Nutr, 87(suppl), 1562S-1566S.

Peyron, M.A., Mioche, L. and Culioli, J. (1994). Bite force and sample deformation during hardness assessment of viscoelastic models of food. Journal of Texture Studies 24, 5976.

Peyron, M. A., Blanc, O., Lund, J. P., \& Woda, A. (2004). Influence of age on adaptability of human mastication. Journal of Neurophysiology, 92(2), 773-779.

Pietrasik, Z., Aalhus, J. L., Gibson, L. L., \& Shand, P. J. (2010). Influence of blade tenderization, moisture enhancement and pancreatin enzyme treatment on the processing characteristics and tenderness of beef semitendinosus muscle. [Research Support, Non-U.S. Gov't]. Meat Sci, 84(3), 512-517. doi: 10.1016/j.meatsci.2009.10.006

Pietrasik, Z., \& Shand, P. J. (2004). Effect of blade tenderization and tumbling time on the processing characteristics and tenderness of injected cooked roast beef. Meat Sci, 66(4), 871-879. doi: https://doi.org/10.1016/j.meatsci.2003.08.009

Savell, J. W., Smith, G. C., \& Carpenter, Z. L. (1977). Blade tenderization of four muscles from three weight-grade groups of beef. Journal of Food Science, 42(4), 866-870. doi: 10.1111/j.1365-2621.1977.tb12625.x

Solemdal, K., Sandvik, L., Willumsen, T., Mowe, M., \& Hummel, T. (2012). The impact of oral health on taste ability in acutely hospitalized elderly. [Research Support, Non-U S Gov't]. PLoS One, 7(5), 3.

Sura, L., Madhavan, A., Carnaby, G., \& Crary, M. A. (2012). Dysphagia in the elderly: management and nutritional considerations. [Review]. Clin Interv Aging, 7, 287-298. doi: 10.2147/CIA.S23404

Tada, A., \& Miura, H. (2014). Systematic review of the association of mastication with food and nutrient intake in the independent elderly. [Review]. Arch Gerontol Geriatr, 59(3), 497-505.

Tracy, J. F., Logemann, J. A., Kahrilas, P. J., Jacob, P., Kobara, M., \& Krugler, C. (1989). Preliminary observations on the effects of age on oropharyngeal deglutition. [Research Support, U S Gov't, P H S]. Dysphagia, 4(2), 90-94. 
Vandenberghe-Descamps, M., Labouré, H., Prot, A., Septier, C., Tournier, C., Feron, G., \& Sulmont-Rossé, C. (2016). Salivary Flow Decreases in Healthy Elderly People Independently of Dental Status and Drug Intake. Journal of Texture Studies, 47(4), 353-360. doi: 10.1111/jtxs.12191

Vandenberghe-Descamps, M., Labouré, H., Septier, C., Feron, G., \& Sulmont-Rossé, C. (2017). Oral comfort: A new concept to understand elderly people's expectations in terms of food sensory characteristics. Food Quality and Preference. doi: http//dx.doi.org/10.1016/j.foodqual.2017.08.009

Vandenberghe-Descamps, M., Sulmont-Rossé, C., Feron, G., \& Labouré, H. (submitted). Impact of easy-to-do culinary techniques on meat shear force and water content. Journal of Texture Study.

Veyrune, J. L., \& Mioche, L. (2000). Complete denture wearers: electromyography of mastication and texture perception whilst eating meat. Eur J Oral Sci, 108(2), 83-92. 


\section{FIGURE CAPTIONS}

Figure 1. Blade tenderizer.

Figure 2. Food comfortability questionnaire developed based on the results of focus groups organized with elderly people.

Figure 3. Chicken breast: impact of culinary proces ses on dryness and meltingness. BT: blade tenderizer; M: marinade; LT: low-temperature cooking. According to post-hoc analyses, samples associated with the same uppercase letters (A, B) are not significantly different for dryness; samples associated with the same lowercase letters ( $a, b)$ are not significantly different for meltingness $(\mathrm{p}>0.05)$.

Figure 4. Roast beef: impact of culinary processes on oral comfort (4a), easiness to masticate (4b) and the texture attributes dryness and tenderness (4c). BT: blade tenderizer; M: marinade; LT: low-temperature cooking. For the histograms, the vertical bars stand for the standard error of the mean. According to post-hoc analyses, samples associated with the same letters $(a, b)$ are not significantly different ( $>00.05$; Figure 4c: uppercase letters $(A, B)$ stand for dryness; lowercase letters (a,b) stand for tenderness).

Figure 5. Beefsteak: impact of culinary processes on easiness to cut with molars. BT: blade tenderizer; M: marinade. The vertical bars stand for the standard error of the mean. According to post-hoc analyses, samples associated with the same letters (a,b) are not significantly different $(\mathrm{p}>0.05)$. 
Table 1: For each product, characterization of the samples.

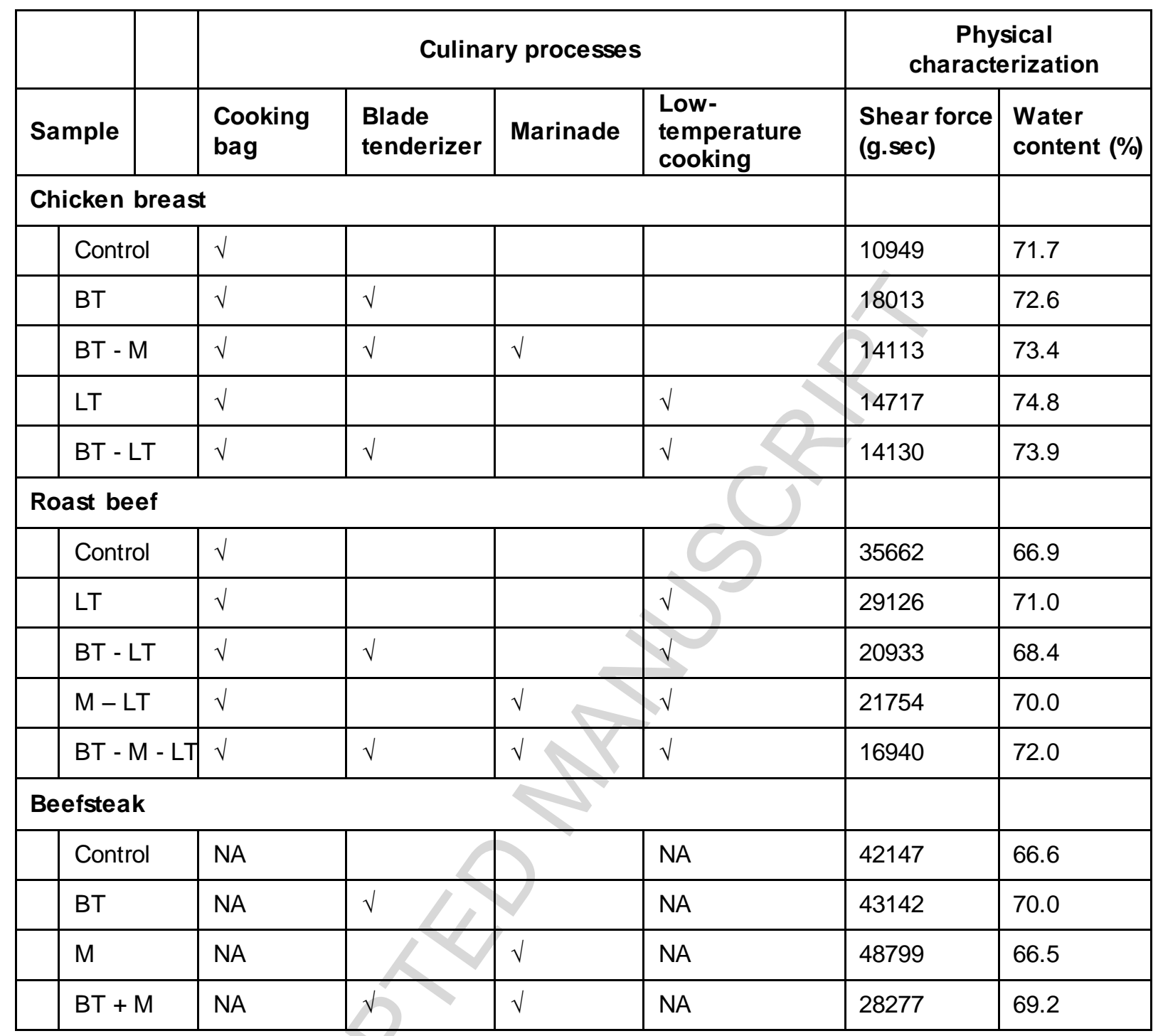


Table 2: Impact of culinary processes: results of the one-way ANOVAs performed for each product and for each attribute of the oral comfort questionnaire (F-value of the sample effect and significance level: $* \mathbf{p}<0.05 ; * * \mathbf{p}<0.01 ; * * * p<0.001)$.

\begin{tabular}{|c|c|c|c|c|}
\hline & Attributes & Chicken breast & Roast beef & Beefsteak \\
\hline General question & Comfort & 0.578 & $<0.001^{\star \star \star}$ & 0,629 \\
\hline \multirow{5}{*}{ Bolus formation } & Incisor & 0.584 & $0,038^{\star}$ & 0,460 \\
\hline & Molar & 0.338 & $0,035^{\star}$ & $0,037^{\star}$ \\
\hline & Masticate & 0.506 & $0,006^{\star *}$ & 0,052 \\
\hline & Humidify & 0.132 & $0,021^{*}$ & 0,548 \\
\hline & Swallow & 0.152 & 0,070 & 0,481 \\
\hline $\begin{array}{l}\text { Time to form food } \\
\text { bolus }\end{array}$ & Time & 0.436 & 0,064 & 0,696 \\
\hline \multirow{5}{*}{ Mouth pain } & Burning & 0.261 & 0,475 & 0,400 \\
\hline & Muscular & 0.765 & 0,176 & 0,829 \\
\hline & Articular & 0.960 & 0,149 & 0,725 \\
\hline & Dental & 0.700 & 0,259 & 0,572 \\
\hline & Gum & 1.000 & 0,124 & 0,891 \\
\hline \multirow{10}{*}{ Texture } & Sticky & 0.565 & 0,096 & 0,350 \\
\hline & Stringy & 0.341 & 0,055 & 0,718 \\
\hline & Greasy & 0.962 & 0,995 & 0,144 \\
\hline & Dry & $0.024^{\star}$ & $<0.001^{\star \star \star}$ & 0,282 \\
\hline & Doughy & 0.281 & 0,418 & 0,356 \\
\hline & Melting & $0.010^{\star *}$ & $0,045^{\star}$ & 0,248 \\
\hline & Firm & 0.208 & $0,041^{*}$ & 0,310 \\
\hline & Hard & 0.287 & $0,021^{*}$ & 0,271 \\
\hline & Tender & 0.086 & $0,001^{\star \star \star}$ & 0,142 \\
\hline & Juicy & 0.888 & $0,012^{\star}$ & 0,624 \\
\hline \multirow{5}{*}{ Flavor } & Taste intense & 0.642 & 0,234 & 0,506 \\
\hline & Salty & 0.730 & 0,817 & 0,291 \\
\hline & Sweet & 0.901 & 0,904 & 0,731 \\
\hline & Sour & 0.442 & 0,950 & 0,357 \\
\hline & Bitter & 0.888 & 0,412 & 0,569 \\
\hline
\end{tabular}


Table 3: Impact of oral health: result of the three-way ANCOVA performed for each attribute of the oral comfort questionnaire (normalized coefficients and significance levels: $* \mathbf{p}<0.05 ; * * \mathbf{p}<0.01 ; * * * \mathbf{p}<0.001)$.

\begin{tabular}{|c|c|c|c|c|c|}
\hline & Attributes & $\begin{array}{l}\text { Sample } \\
\text { effect }\end{array}$ & $\begin{array}{l}\text { Dentition } \\
\text { effect }\end{array}$ & $\begin{array}{l}\text { Resting saliva } \\
\text { effect }\end{array}$ & $\begin{array}{l}\text { Stimulated } \\
\text { saliva effect }\end{array}$ \\
\hline General question & Comfort & $* * *$ & 0.015 & 0.045 & 0.027 \\
\hline \multirow{5}{*}{$\begin{array}{l}\text { Easiness } \\
\text { to form food bolus }\end{array}$} & Incisor & $\star * \star$ & 0.113 & $0.208^{\star \star \star}$ & -0.098 \\
\hline & Molar & $\star * \star$ & 0.021 & 0.002 & $0.110^{\star}$ \\
\hline & Masticate & 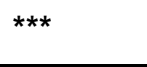 & 0.059 & $0.115^{\star}$ & -0.066 \\
\hline & Humidify & *** & $0.117^{\star *}$ & $0.201^{\star \star \star}$ & $-0.233^{\star \star \star}$ \\
\hline & Swallow & *** & $0.139^{\star \star}$ & $0.194^{\star \star \star}$ & $-0.242^{\star \star \star}$ \\
\hline \multicolumn{2}{|c|}{ Time to form food bolus } & $* * *$ & $0.172^{\star \star \star}$ & $0.176^{\star \star \star}$ & $-0.197^{\star \star \star}$ \\
\hline \multirow{5}{*}{ Pain } & Burning & NS & -0.022 & -0.059 & -0.014 \\
\hline & Muscular & NS & $-0.191^{\star \star \star}$ & $-0.116^{\star}$ & -0.051 \\
\hline & Articular & $\star *$ & $-0.180^{\star \star \star}$ & $0.109^{\star}$ & $-0.155^{\star \star}$ \\
\hline & Dental & NS & -0.019 & $0.129^{\star}$ & -0.105 \\
\hline & Gum & NS & $0.133^{\star \star}$ & 0.087 & $-0.171^{\star \star}$ \\
\hline \multirow{10}{*}{ Texture } & Sticky & *** & 0.40 & $-0.142^{\star \star}$ & 0.004 \\
\hline & Stringy & $* * *$ & 0.075 & -0.074 & -0.065 \\
\hline & Greasy & NS & -0.060 & $-0.162^{\star \star}$ & 0.017 \\
\hline & Dry & $* * *$ & $-0.156^{\star \star \star}$ & -0.033 & -0.006 \\
\hline & Doughy & *** & $0.105^{\star}$ & -0.054 & $-0.184^{\star \star \star}$ \\
\hline & Melting & $* * *$ & $0.139^{\star \star}$ & -0.045 & 0.076 \\
\hline & Firm & *** & -0.017 & 0.001 & $-0.156^{\star \star}$ \\
\hline & Hard & *** & -0.016 & $-0.178^{\star \star \star}$ & -0.005 \\
\hline & Tender & *** & $0.139^{\star \star}$ & $0.132^{\star *}$ & -0.109 \\
\hline & Juicy & *** & $0.115^{\star \star}$ & 0.052 & -0.076 \\
\hline \multirow{5}{*}{ Flavor } & Taste intense & $* * *$ & $0.116^{\star \star}$ & $-0.171^{\star \star \star}$ & 0.073 \\
\hline & Salty & NS & $0.133^{\star \star}$ & 0.024 & -0.167 \\
\hline & Sweet & NS & -0.059 & -0.043 & -0.046 \\
\hline & Sour & NS & -0.066 & 0.002 & -0.106 \\
\hline & Bitter & NS & -0.041 & -0.002 & $-0.191^{\star *}$ \\
\hline
\end{tabular}

Regarding dental status, a positive coefficient means that good dental status group rated the item higher compared to the poor dental status group. Regarding resting and stimulated 
salivary flow, a positive coefficient reflects a positive correlation between the item score and the salivary flow.

Comment citer ce document : 


\section{Highlights}

- Easy-to do culinary techniques improved significantly oral comfort when eating meat

- Oral health impairments do not seem to have an impact on oral comfort assessment

- Advices on meat preparation should be given to elderly people willing to eat meat 


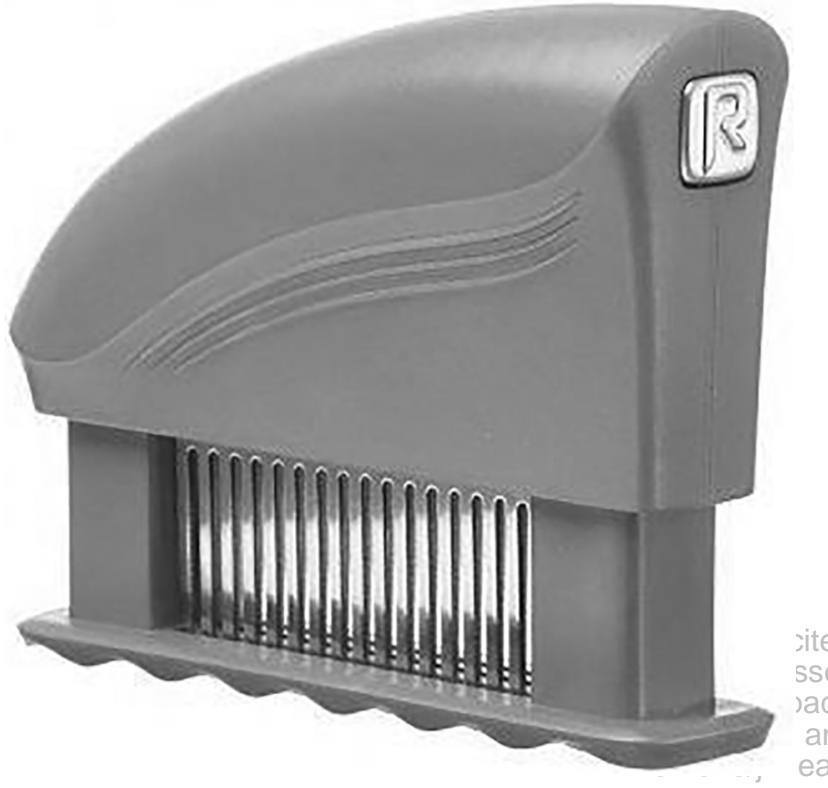

Figure 1 


\begin{tabular}{|l|c|l|l|l|l|}
\hline GENERAL QUESTION & $\begin{array}{c}\text { Very } \\
\text { uncomfortable }\end{array}$ & Uncomfortable & $\begin{array}{c}\text { Moderately } \\
\text { Comfortable }\end{array}$ & Comfortable & $\begin{array}{c}\text { Very } \\
\text { comfortable }\end{array}$ \\
\hline This food is... & & & & & \\
\hline
\end{tabular}

\begin{tabular}{|l|l|l|l|l|l|l|}
\hline BOLUS FORMATION & Impossible & $\begin{array}{c}\text { Very } \\
\text { difficult }\end{array}$ & Difficult & $\begin{array}{c}\text { Moderately } \\
\text { easy }\end{array}$ & Easy & $\begin{array}{c}\text { Very } \\
\text { easy }\end{array}$ \\
\hline To cut this food with your incisor is... & & & & & & \\
\hline To cut this food with your molar is... & & & & & & \\
\hline To masticate this food is... & & & & & & \\
\hline To humidify this food with saliva is... & & & & & & \\
\hline To swallow this food is... & & & & & & \\
\hline
\end{tabular}

\begin{tabular}{|l|l|l|l|l|l|l|}
\hline TIME TO FORM FOOD BOLUS & $\begin{array}{c}\text { Impossible } \\
\text { to swallow }\end{array}$ & Very long & Long & $\begin{array}{c}\text { Moderately } \\
\text { brief }\end{array}$ & Brief & $\begin{array}{c}\text { Very } \\
\text { brief }\end{array}$ \\
\hline Time needed to form the bolus is... & & & & & & \\
\hline
\end{tabular}

\begin{tabular}{|l|l|l|l|l|}
\hline MOUTH PAIN & Not at all & Little & A lot & Extremely \\
\hline Does eating the food bring a burning or spicy sensation? & & & & \\
\hline Does eating the food bring muscular pain? & & & & \\
\hline Does eating the food bring articular pain? & & & & \\
\hline Does eating the food bring dental pain? & & & & \\
\hline Does eating the food bring gum pain? & & & \\
\hline
\end{tabular}

\section{TEXTURE}

\begin{tabular}{|l|l|l|l|}
\hline Not at all & Little & A lot & Extremely \\
\hline & & & \\
\hline & & & \\
\hline & & & \\
\hline & & & \\
\hline & & & \\
\hline & & & \\
\hline & & & \\
\hline
\end{tabular}

\begin{tabular}{|l|l|l|l|l|}
\hline FLAVOR & Not at all & Little & A lot & Extremely \\
\hline Is this food intense in taste? & & & & \\
\hline Is this food salty? & & & & \\
\hline Is this food sweet? & & & & \\
\hline Is this food sour? & & & & \\
\hline Is this food bitter? & & & \\
\hline
\end{tabular}


Chicken breast

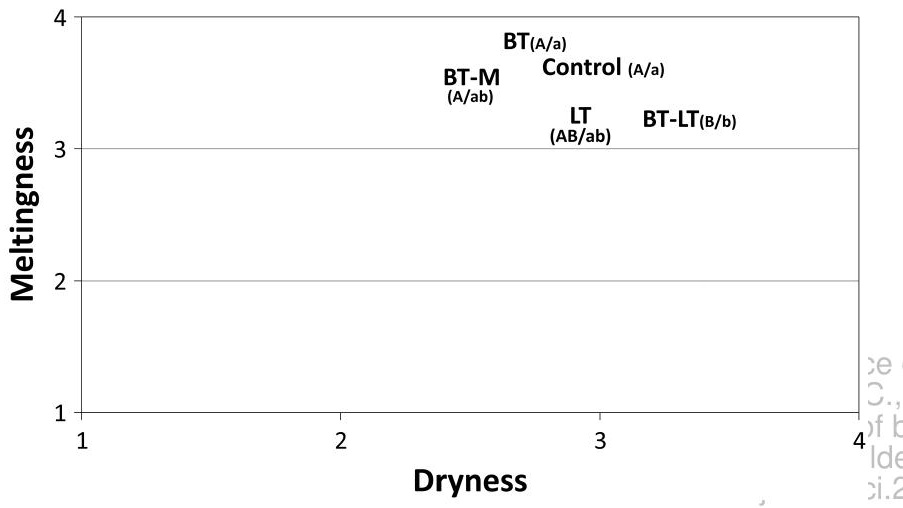

Figure 3 
(a)

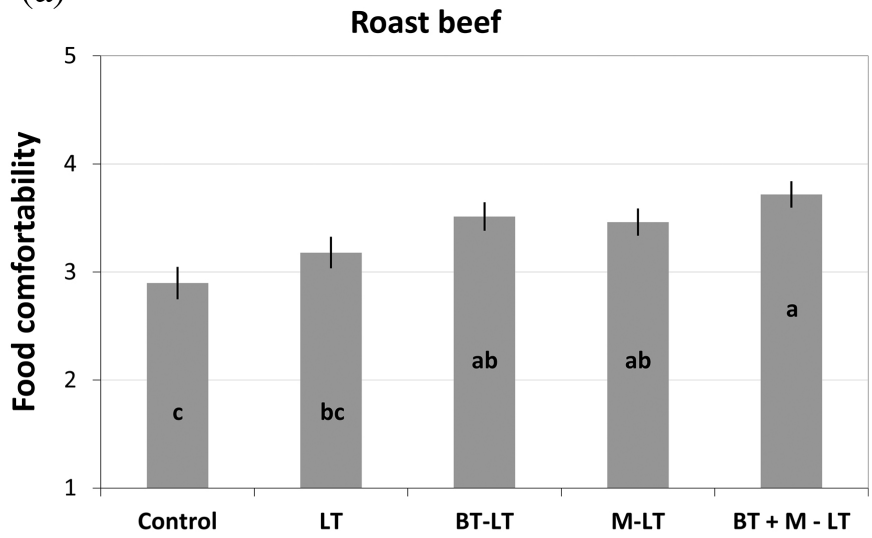

(b) Roast beef

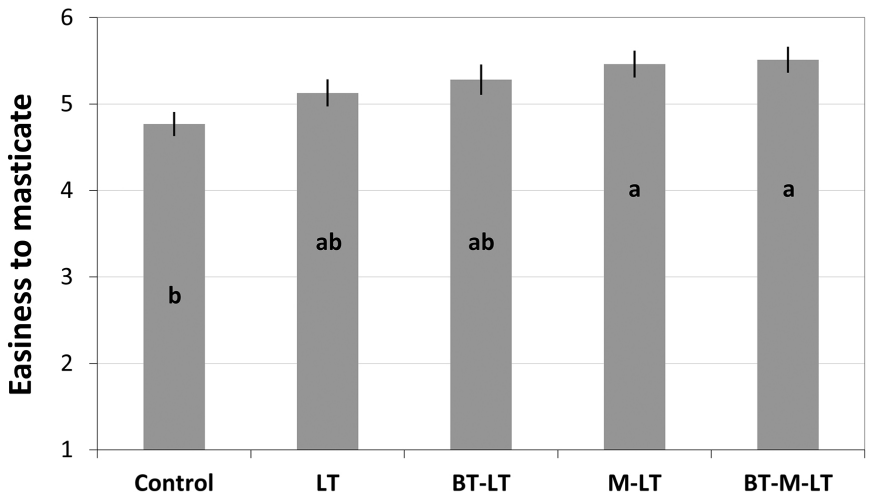

(c) Roast beef

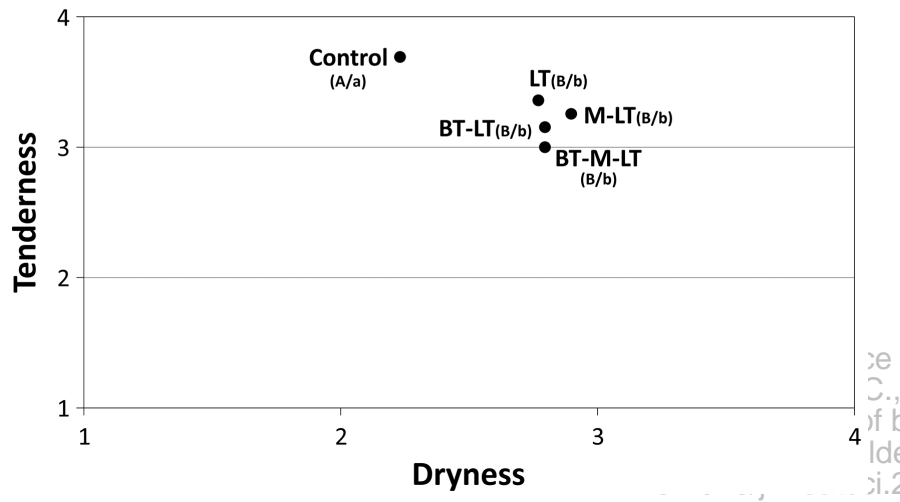

Figure 4 
Beefsteak

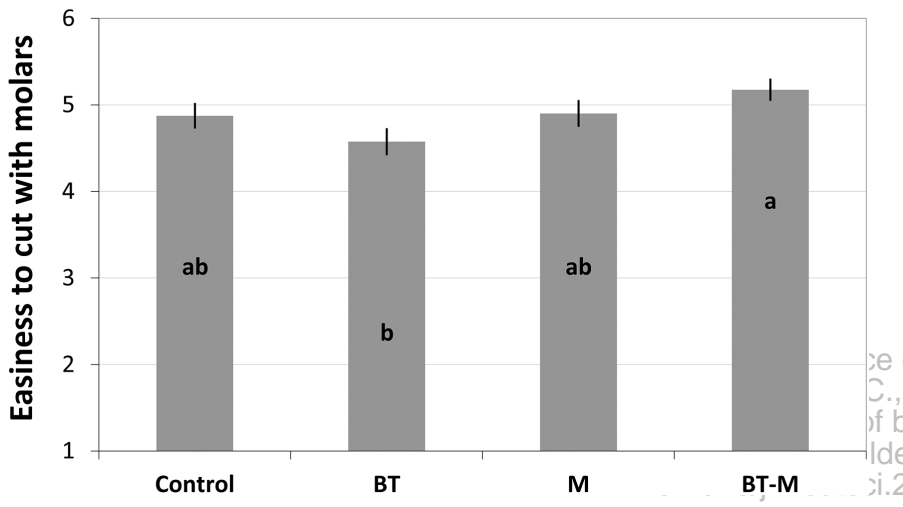

Figure 5 